\title{
Kaizen Event and Innovation Performance in Malaysian Automotive Industry
}

\author{
Suzaituladwini Hashim, Anis Fadzlin Mohd Zubir, Juriah Conding, Nurzatul Ain Seri \\ Lanang Jaya \\ Dept. of Accounting and Finance, Universiti Pendidikan Sultan Idris \\ 35900 Tanjung Malim, Perak, Malaysia \\ Tel: 60-194-476-920Ｅ-mail: adwinihashim@yahoo.com
}

Nurul Fadly Habidin (Corresponding author)

Dept. of Management and Leadership, Universiti Pendidikan Sultan Idris

35900 Tanjung Malim, Perak, Malaysia

Tel: 60-5450-6468Ｅ-mail: fadly@fpe.upsi.edu.my

Received: July 2, 2012 Accepted: July 16, 2012 Published: December 1, 2012

doi:10.5296/bms.v3i2.2029 URL: http://dx.doi.org/10.5296/bms.v3i2.2029

\begin{abstract}
Kaizen Event (KE) has been growing in popularity since the mid 1990s, to date, there has difficult to find empirical research on the determinants of KE effectiveness. KE are an increasingly common organizational improvement mechanism aimed at work area transformation and employee development. The purpose of this paper is to identify the KE constructs and Innovation Performance (IP) measures for Malaysian automotive industry and also to develop research model of the $\mathrm{KE}$ and IP measures relationship for Malaysian automotive industry. A conceptual model based on previous studies and using Structural Equation Modeling (SEM) has been proposed. This model will be used to study the relationship between KE practices and IP for Malaysian automotive industry. Based on the proposed conceptual model and reviewed, research hypotheses are being developed. The paper culminates with suggested future research work.
\end{abstract}

Keywords: Kaizen, Innovation, Employee involvement, Performance, Automotive 


\section{Introduction}

The automotive sector in Malaysia is one of priority a field under (Industrial Master Plan 3 (IMP3)) is coordinated by the Ministry International Trade and Industry (MITI). In 2006, MITI has introduced a National Automotive Policy (NAP) to promote the local automotive sector more competitive and enhance the development of the automotive sector more organized. NAP is seen an important basis for economic change towards a more develop. It is also able to change the mindset of individuals who are involved directly and indirectly to more creative and critical thinking in order to compete globally.

Among the objectives of the NAP is to ensure that the development of the automotive industry is organized and structured as well as increasing capacity and competitiveness in the long term due to market liberalization; create a conductive investment environment to encourage additional new investment; enhance the competitiveness of the national car manufacturer through strategic alliances; encourage the development of new technology and latest in the domestic automotive industry; continuing to increase Bumiputera participation in the automotive industry; improve safety standards for consumer safety as well as promoting activities in the field of environmentally friendly and improve the implementation of the policy instrument available under the NAP.

Based on the objectives outlined, it can be seen that the importance of activities that involve the continuous activity in order to improve the IP. The challenges in automotive industry were increased. Then by that, the strategic direction and policy framework for the automotive industry must be reviewed (Venkataiah and Sagi, 2012). Malaysian automotive industry must focus on quality improvement to fulfil the specific needs and to exceed the customer expectations.

To achieve KE, firms must promote organisational learning to enhance knowledge that can be utilised in the future (Baker and Sinkula, 1999). Based on the objectives of the NAP, national automotive industry must continue to innovate on their products. Processes to innovate should be done continuously. KE is one of the practices that lead to Continuous Improvement (CI) and can lead to innovation elements. The benefits of KE may be associated with both individual workers as well as the company performance. KE has proven to be effective as an organizational improvement mechanism which support employee development and improves the work environment (Farris et al., 2009).

By these issues, this paper aims to assess the implementation of KE will increase IP or not. Besides that, this paper looks at the methods of implementation of KE in automotive industry.

\section{Review of Related Literature}

\subsection{Kaizen Event (KE)}

KE comes from the Toyota system that starts in the 1970s (Shediran, 1997). KE focused on a structured improvement project, using the approach of "cross-functional team" to improve the target work area, with specific targets (Farris et al., 2008). The word Kaizen is derived from the Japanese word for continuous improvement. Further, the word is a combination of two 
Japanese words, namely ' $k a i$ ' means change and 'zen' means continuous improvement (iSixSigma LLC, 2004). In the U.S. KE was also called Kaizen Blitz, which means continuous and repeated improvement. It is one of the manufacturing strategies in lean manufacturing or in Toyota Production System (TPS) (Anh et al., 2011). KE aims to control the operation of the working environment; it also aims to improve processes and efficiency of workers (Brunet et al., 2003; Ventakiah and Sagi, 2012). According Doolen et al., (2008) Kaizen is one of the mechanisms of structural improvement that could be implemented by any organization.

$\mathrm{KE}$ has proved to be an effective tool to change the work culture, work proceeding, and work experience. This statement is supported by Farris et al. (2009) which shows that the KE capable of adaption to the organization culture. It is seen as one of lean tools that help to ensure that operations become more smoothly by removing wasteful activities that are of no value from a customer perspective (Venkataiah and Sagi, 2012). According to Brunet et al. (2003), almost the same that KE can help to avoid wastage by employees with a full sense of responsibility, punctuality and as a tool for improvement and change. Therefore, Table 1.0 below shows the factors from previous studies for implementing KE.

Table 1.0. KE factor from previous studies

\begin{tabular}{|c|c|c|}
\hline Melnyk et al. (1998) & $\begin{array}{l}\text { Venkataiah and Sagi } \\
\text { (2012) }\end{array}$ & Bateman and Rich (2003) \\
\hline 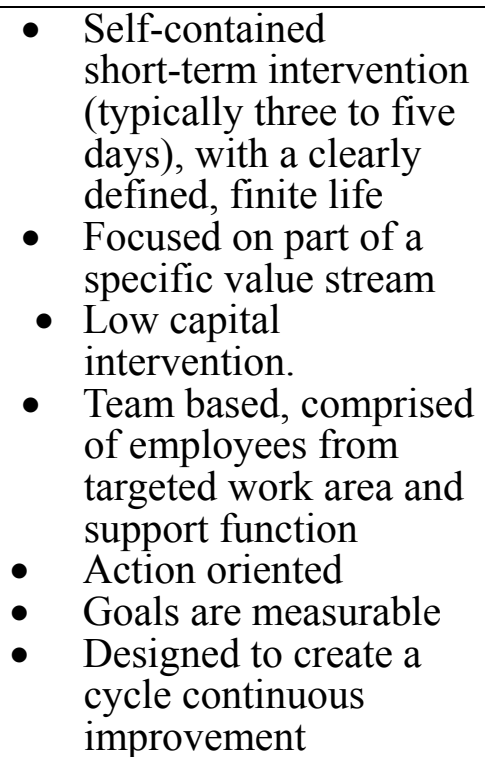 & $\begin{array}{ll}\text { - } & \text { Participation in decision } \\
\text { making } \\
\text { - }\end{array}$ & $\begin{array}{ll}\text { - } & \text { Resource availability } \\
\text { - } & \text { Recognition of need for } \\
\text { - } & \text { Culture that support } \\
& \text { change } \\
\text { - } & \text { Kaizen program } \\
\text { champion quality } \\
\text { - Team leader quality } \\
\text { - Management support } \\
\text { - } \\
\text { - Cmployee turnover } \\
\text { - } \text { Meamunication quality } \\
\text { - } \text { alignment } \\
\text { Ability to financially } \\
\text { justify event }\end{array}$ \\
\hline Doolen et al. (2008) & Farris et al. (2008) & Patil (2003) \\
\hline $\begin{array}{l}\text { - Goal difficulty } \\
\text { - Management support }\end{array}$ & $\begin{array}{ll}\text { - } & \text { Goal clarity } \\
\text { - } & \text { Team functional } \\
\text { - } & \text { Tepresentation } \\
\text { - } & \text { autonomy }\end{array}$ & $\begin{array}{ll}\text { - } & \text { Employee involvement } \\
\text { - } & \text { Job security } \\
\text { - } & \text { Training } \\
\text { - } & \text { Stanployee needs surveys operating } \\
& \text { procedures (SOPs) } \\
\text { - } & \text { Follow-up reviews } \\
\text { - } & \text { Time for completion of } \\
& \text { action items } \\
\text { - } & \text { Strategic alignment } \\
\text { - Knowledge sharing }\end{array}$ \\
\hline
\end{tabular}


Based on previous studies, this study defines a KE to three factors of follow-up activities, working area of impact and employee skill and effort. Three of these factors appear more suitable for the automotive industry in Malaysia. The Table 2.0 below shows a list of more detailed study related to three factors selected.

Table 2.0. Previous studies about KE

\begin{tabular}{|l|l|l|l|}
\hline Author & $\begin{array}{l}\text { Follow up } \\
\text { activities }\end{array}$ & $\begin{array}{l}\text { Working } \\
\text { area impact }\end{array}$ & $\begin{array}{l}\text { Employee skill } \\
\text { and effort }\end{array}$ \\
\hline Anh et al. $(2011)$ & $*$ & & $*$ \\
\hline Doolen et al. $(2008)$ & $*$ & $*$ & $*$ \\
\hline Farris et al. $(2009)$ & $*$ & $*$ & $*$ \\
\hline $\begin{array}{l}\text { Venkataiah and Sagi } \\
(2012)\end{array}$ & & $*$ & $*$ \\
\hline Farris et al. $(2008)$ & & $*$ & $*$ \\
\hline Van Aken et al. $(2010)$ & $*$ & & $*$ \\
\hline $\begin{array}{l}\text { Recht and Wilderom } \\
(1998)\end{array}$ & & $*$ & $*$ \\
\hline Glover et al. $(2008)$ & $*$ & $*$ & $*$ \\
\hline Lyu (1996) & $*$ & & $*$ \\
\hline Marksberry (2010) & & $*$ & $*$ \\
\hline Melnyk et al. $(1998)$ & & $*$ & \\
\hline Bateman and Rich (2003) & & $*$ & \\
\hline Patil (2003) & $*$ & & \\
\hline
\end{tabular}

\subsection{KE Factors}

\subsubsection{Follow-up Activities}

Follow-up activity is the action that reflects the KE. It involves the work area employees to complete the action. Follow-up activities also give freedom to the employees to make any changes and innovation. However all the changes and innovations made by employees will be related to KE goals (Glover et al., 2008).

\subsubsection{Working Area Impact}

$\mathrm{KE}$ activities affect the work area. Generally KE activities can help employees who are improving their work area (Doolen et al., 2008). Moreover, Farris et al. (2008) also states that the $\mathrm{KE}$ is a complex phenomenon organizational and has the potential to affect both systems, the technical system (work are performance) and social systems (participation employees and of work areas employees). Impact learning and stewardship when employees feel a shared of responsibility, freely share information, understand how their work fits into the "bigger picture" and impacts experimentation when employee test new ideas to help themselves learn.

\subsubsection{Employee Skill and Effort}

Employee performance fundamentally depends on many factors like performance appraisals, 
employee motivation, employee satisfaction, compensation, training and development, job security, organizational structure and other. KE can improve the employee knowledge in managing an organization with more systematic and successful (Butterworth, 2001; Tanner and Roncarti, 1994). It also can be one of the platforms for knowledge employees in principles, tools and techniques for continuous improvement (Watson, 2002).

\subsection{Innovation Performance}

Innovation is seen as the economic needs which can provide a return value to an organization in the short and long term. The word innovation is also found in corporate mission of most organizations. Damanpour (1991), organizational innovation combines the development and implementation of new ideas, systems, products, or technologies. There are several previous studies that describe the definition of IP in Table 3.0.

Table 3.0. Dimension Operational

\begin{tabular}{|l|l|}
\hline Dimension & Dimension operational \\
\hline \multirow{5}{*}{$\begin{array}{l}\text { Innovation } \\
\text { Performance }\end{array}$} & $\begin{array}{l}\text { Suggested that innovation is equated with the adoption and } \\
\text { application of new knowledge and practices, including the } \\
\text { ability of an organisation to adopt or create new ideas and } \\
\text { implement these ideas in developing new and improved } \\
\text { products, services, and work processes and procedures } \\
\text { (Bates and Khasawneh, 2005). }\end{array}$ \\
\hline $\begin{array}{l}\text { Innovation is seen as a process which results from various } \\
\text { interactions among different actors (Doloreux, 2004). }\end{array}$ \\
\hline $\begin{array}{l}\text { Innovation requires a comprehensive network to accelerate } \\
\text { the information dissemination and need information and } \\
\text { resources that can be trusted (Dewick and Miozzo, 2004). }\end{array}$ \\
\hline $\begin{array}{l}\text { Innovations are manifested in a new product, service, } \\
\text { technology and administrative practice (Zaugg and Thom, } \\
\text { 2003). }\end{array}$ \\
\hline $\begin{array}{l}\text { Therefore, briefly the IP refers to the level of innovation organization, effects from } \\
\text { the implementation of several processes and influenced from specific factors. }\end{array}$ \\
\hline
\end{tabular}

Innovation is an important element in the manufacturing industry because it helps the organization to be more competitive in the market (Weerawardena et al., 2006). In competitive markets, enterprises must increase their knowledge to adapt to new products and technology, and continuously distribute this knowledge to all employees. Based on an organization's internal factors, the nature of innovation can involve technical, product, and process innovation. These internal factors include knowledge and skill resources, physical and management systems, and values and norms. The external factors include customers, competitors, statutes, and technology (Kanji, 1996; Tang, 1998; Yamin et al. 1999; Gopalakrishnan and Bierly, 2001; Prajogo \& Sohal, 2003). Next, based on previous studies, innovation can divided into several types in Table 4.0 below. 
Table 4.0. Types of Innovation

\begin{tabular}{|l|l|}
\hline Authors & Types \\
\hline Yamin et al. (1999) & $\begin{array}{l}\text { Administrative innovation } \\
\text { Product innovation } \\
\text { Process innovation }\end{array}$ \\
\hline $\begin{array}{l}\text { Gopalakrishnan and Bierly } \\
(2001)\end{array}$ & $\begin{array}{l}\text { Administrative and technical } \\
\text { innovations } \\
\text { Product and process innovations } \\
\text { Radical and incremental innovations }\end{array}$ \\
\hline Prajogo et al. (2004) & $\begin{array}{l}\text { Product innovation } \\
\text { Process innovation }\end{array}$ \\
\hline
\end{tabular}

Based on the table above, innovation can be concluded that it's divided into innovation administrative, products, and processes. But in this paper the innovation were classified into three types, namely innovation environment, employee innovation and technology innovation. Three attributes of this innovation more emphasis on administrative features and innovations process.

\subsection{KE Implementation in Manufacturing Affected IP}

Developments in research on $\mathrm{KE}$ indicate that the $\mathrm{KE}$ is increasingly popular in the mid-1990s (Sheridan, 1997). It was also supported by previous studies of recent and relevant to the implementation of lean manufacturing within the organization can improve organizational performance measurement (Fullerton et al., 2003; Hopp and Spearmen, 2004). In addition, lean manufacturing one of the mechanisms which can enhance OP is the KE (Sheridan, 1997; Melnyk et al., 1998; Bradley and Willett, 2004). KEs generally affect the first two areas, namely; in repair work areas, processes, and products. Second, the impact on human resource development is increase in knowledge, skills, and attitudes of employees (KSAs). Both of these effects are needed to create the organizational culture towards continuous improvement in the long-term (Sheridan, 1997; Melnyk et al., 1998; Laraia et al., 1999; Farris et al., 2008).

Previous studies showed that many companies are using KE in their operations. Some have successfully improved their quality, financial and management; there are those who have failed due to several factors such as organizational culture and work environment (Farris et al., 2008). Then, according Doolen et al. (2008) KE to improve OP because KE has more limited scope and does not involve a lot of capital to achieve company objectives. A culture of KE will eventually also yield large innovations in the form of compounded improvement. Kaizen includes making changes to trading/investment systems, retesting, implementing, and again monitoring results.

Innovation is based on the attitudes of people who can think creatively and innovatively (Bessant et al., 2001). Innovation and learning growth is very important in an organizational setting because it will help the organization more competitive in the global market. Innovation will happen if the employees have KSA (Eker and Pala, 2008). In the 
implementation of the KE a great emphasis on employee KSA for KE does not involve new technology and it only involves existing technology and renewable. It was supported by a study conducted by the Anh et al. (2011) in Japan that showed that the KE practices affect to financial performance in terms of savings on maintenance costs. It can also increase the internal business process; it can be low power distance and low uncertainty avoidance.

Hence, KE practice can improve the high cross-functional cooperation (Bradley and Willett, 2004). The existence of high cross functional cooperation in the organization will give indirect impact on IP. Kaizen concept which to make the innovation elements appear when the kaizen concept was practices. Additionally, KE promises to dramatically improvements performance and use cross-functional project team. It is similar to the Business Process Reengineering (BPR) as it also uses cross-functional reengineering projects to improve performance. Both of these practices have the same character and it is a key element in Total Quality Management (TQM) approach (Doolen et al., 2008). But there were differences between the KE with the BPR in terms of capital usage and execution time. KE is designed for low capital and short execution time. While, BPR involves using new technologies that require large capital and take more time to implement it (Grover, 1999; Doolen et al., 2008). Dramatic improvement particularly in the OP will have an impact on enhancing the skills of employees and managers. According Lyu (1996) workers and managers are recommended for continue to innovate and take risks as an opportunity to fulfill customers' needs, wants and preferences. Kaizen have proven useful in various fields of automotive, security (services), manufacturing, health (Lyu, 1996; Bateman and Rich, 2003; Farris et al., 2008).

KE practice will have an impact on IP within the scope of technologies uses. This is because the scope of the changes requested in the KE is limited. It only focused on specific processes without involving organizational change and new technology (Laraia et al., 1999; Farris et al., 2009). Improvements to be made will be determined first by the organization management. $\mathrm{KE}$ only requires a small capital to do so because the organization will be making improvements to existing processes and technologies without involving the purchase of the latest technology (Sheridan, 1997b). Therefore, KE was not requiring large capital, but instead it more to approach member's thinking. It promotes the process of thinking and creative self to solve problems systematically and using a suitable structured (Bicheno, 2001).

\section{A Proposed Conceptual Model}

Based on comprehensive review of previous study, a conceptual model has been proposed to model the relationship between KE and IP as presented in Figure 2. This proposed model has adopted from the previous studies. However, some amendments especially on KE practices and IP constructs have been made. 


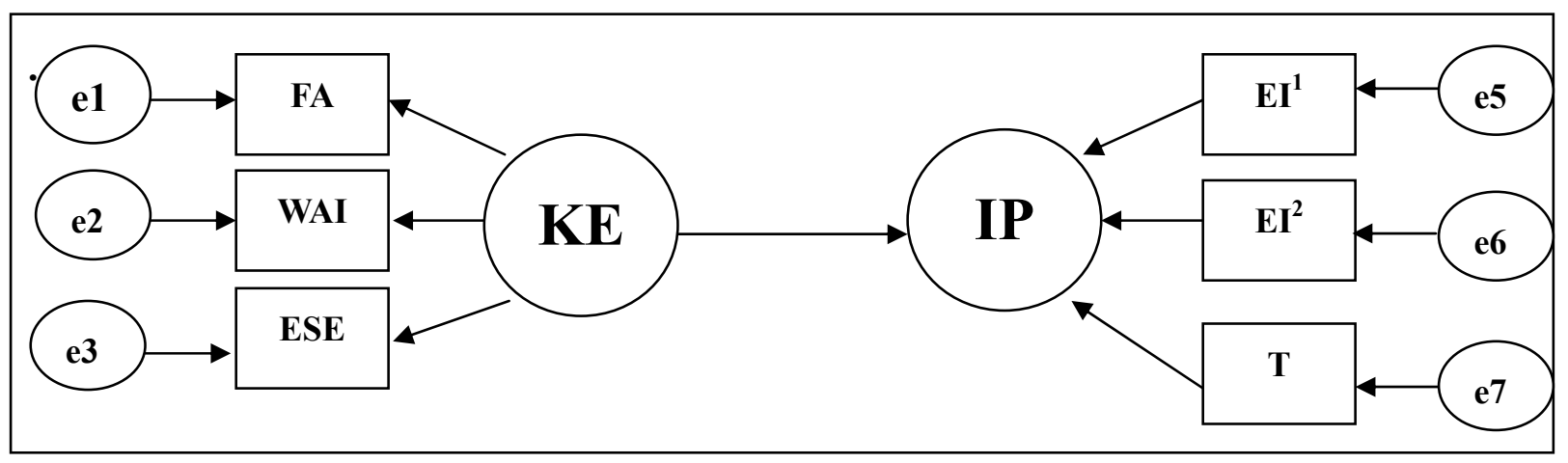

*Note: $\mathrm{KE}=\mathrm{KE}, \quad \mathrm{IP}=\mathrm{IP} \quad \mathrm{FA}=$ Follow-up Activities, WAI=Working Area Impact, $\mathrm{ESE}=$ Employee Skill and Effort, $\mathrm{EI}^{1}=$ Environmental Innovation, $\mathrm{EI}^{2}=$ Employee Innovation, $\mathrm{T}=$ Technology.

Figure 2. A Proposed Research Model

\subsection{Research Hypothesis}

KE have been widely reported to produce positive change in business results and human resource outcomes. However, it can be difficult for many organizations to sustain or improve upon the results of a KE after it concludes (Glover, 2010). KE practices have successfully improved OP; there are those who have failed due to several factors such as organizational culture, working ethics, and internal process (Farris et al., 2008; Anh et al. 2011). KE positively, indirectly related to work area attitude and commitment through accepting changes which suggests that work areas that experience changes in product mix, may be more likely to be accepting of other changes to make innovation (Laraia et al., 1999).

Hence, Terziovski and Sohal (2000) said that KE has positive relationship on improved quality conformance, increased productivity, reduced costs, and increase the transmission capacity. This study was conducted in firms in Australia. Moreover, the study by Bessant et al. (2001) showed that high involvement in the KE can sustain organizational capability. KE is also an effective tool in improving the quality of management and increased desire exceptional management to innovate on their products (Yung, 1996). Therefore:

$H_{1}$ : There is a positive and direct significant relationship between Kaizen event and innovation performance in Malaysian automotive industry.

\subsection{Methodologies}

In this study, sampling method by using structured questionnaire. The population of this study comprised in Malaysian automotive industry. Questionnaires will distribute to respondents from the listing of automotive industry obtained from Malaysian Automotive Component Parts Association (MACPMA), Proton Vendors Association (PVA), and Kelab Vendor Perodua. To analyze the data, one statistical technique was adopted. Structural equation modelling techniques was utilize to perform the require statistical analysis of the data from the survey.

Exploratory factor analysis, reliability analysis and confirmatory factor analysis to test for 
construct validity, reliability, and measurements loading were performed. Having analyzed the measurement model, the structural model was then tested and confirmed. The statistical Package for the Social Sciences (SPSS) version 17 was used to analyze the preliminary data and provide descriptive analyses about thesis sample such as means, standard deviations, and frequencies. Structural Equation Modelling (SEM using AMOS 6.0) will use to test the measurement model.

This study is expected to arrive at the following conclusion: This study has important implication for KE and IP in Malaysian automotive industry. As such, it is expected to benefit both researchers and practitioners.

\section{Future Research}

Many studies have been performed to identify critical success factors for successful implementation KE practices. However, no previous study had tried to investigate the relationship between KE practices and IP, especially amongst automotive industry in Malaysia. A conceptual model has been proposed to examine the relationship between $\mathrm{KE}$ practices and IP for Malaysia automotive industry and to develop research model of the KE and IP measures relationship for Malaysian automotive industry. Based on proposed model and a previous studied, research hypotheses are being develop. The next step of this study is to design a questionnaire, which will be used for pilot study data collection in Malaysia automotive industry.

\section{Conclusion}

In brief, the findings of this research can be benefited, used and contribute not only to academic but also to the industry, especially to the suppliers development, and improvement division and to the Malaysian automotive practitioners as a whole in making the model, and the tool of this study as a benchmark to serve as a guide and reference resources to implement KE practice, and IP.

\section{Acknowledgement}

The researchers would like to acknowledge the Ministry of Higher Education (MOHE) for the financial funding of this research thought Fundamental Research Grant Scheme (FRGS), and Research Management Centre (RMC), UPSI for Research University Grant (RUG).

\section{References}

Anh, P. C., Jing, Z., \& Matsui, Y. (2011). Empirical study on transferability of Kaizen practices. The $11^{\text {th }}$ International DSI and the $16^{\text {th }}$ APDSI Joint Meeting, Taipei, Taiwan, July 12-16, 2011.

Baker, W., \& Sinkula, J. (1999).The Synergistic Effect of Market Orientation and Learning Orientation on Organizational Performance. Journal of the Academy of Marketing Science, 27(4), 411-427. http://dx.doi.org/10.1177/0092070399274002

Bateman, N., \& Rich, N. (2003). “Companies' perceptions of inhibitors and enablers for process improvement activities". International Journal of Operations \& Production 
Management, 23(2), 185-99. http://dx.doi.org/10.1108/01443570310458447

Bates, R., \& Khasawneh, S. (2005). Organizational learning culture, learning transfer climate and perceived innovation in Jordanian organizations. International Journal of Training and Development, 9, 96-109. http://dx.doi.org/10.1111/j. 1468- 2419.2005.00224.x

Bessant, J., Caffyn, S., \& Gallagher, M., (2001). An evolutionary model of continuous improvement behaviour. Technovation, $67-77$. http://dx.doi.org/10.1016/S0166-4972(00)00023-7

Bicheno, J. (2001). "Kaizen and Kaikaku." Manufacturing Operations and Supply Chain Management: The LEAN Approach, Taylor, D, and Brunt, D., eds., London, UK: Thomson Learning, 175-184.

Bradley, J. R., \& Willett, J. (2004). “Cornell Students Participate in Lord Corporation's Kaizen Projects,”. Interfaces, 34(6), 451-459. http://dx.doi.org/10.1287/inte.1040.0103

Brunet, A. P., \& New, S. (2003). "Kaizen in Japan: An Empirical Study". International Journal of Operations and Production Management, 23(12), 1426-1446. http://dx.doi.org/10.1108/01443570310506704

Butterworth, C. (2001). "From Value Stream Mapping to Shop Floor Improvement: A Case Study of Kaikaku.". Manufacturing Operations and Supply Chain Management: The LEAN Approach, Taylor, D, and Brunt, D., eds., London, UK: Thomson Learning, 185-193. Dewick, P., Miozzo, M. "Networks and Innovation: sustainable technologies in Scottish social housing." R\&D Management, 34(3), 323-333.

Doloreux, D., Hommen, L., \& Edquist, C. (2004). Nordic regional innovation system: An analysis of the region of East-Gothia, Sweden. Canadian Journal of Regional Science, 27, $1-25$.

Doolen, T., Van Aken, E., Farris, J., Worley, J., \& Huwe, J. (2008). "Kaizen events and organizational performance: a field study". International Journal of Productivity \& Performance Management, 57 (8), 637-58. http://dx.doi.org/10.1108/17410400810916062

Drickhamer, D. (2004). “Just-In-Time Training”. Industry Week, 253(7), 69.

Eker, M., \& Pala, F. (2008). "The effect of competition, just-in-time production, and total quality management on the use of multiple performance measures: an empirical study". Journal of Economic \& Social Research, 10(1), 35-72.

Farris, J., Van Aken, E., Doolen, T., \& Worley, J. (2008). "Learning from less successful Kaizen events: a case study". Engineering Management Journal, 20(3), 10-20.

Farris, J., Van Aken, E., Doolen, T., \& Worley, J. (2009). “Critical success factors for human resource outcomes in Kaizen events: an empirical study". International Journal of Production Economics, 117(1), 42-65. http://dx.doi.org/10.1016/j.ijpe. 2008.08.051

Fullerton, R.R., McWatters, C.S., \& Fawson, C. (2003). "An examination of the relationships between JIT and financial performance". Journal of Operations Management, 21(4), 383-404. 
http://dx.doi.org/10.1016/S0272-6963(03) 00002-0

Glover, W.J., Van Aken, E.M., Farris, J.A., Doolen, T.L., \& Worley, J.M. (2008). —Kaizen Event Follow-Up Mechanisms and Goal Sustainability: Preliminary Results. Proceedings of the 2008 Industrial Engineering and Research Conference, Vancouver, BC, Canada, May 17-21, 2008.

Gopalakrishnan, S., \& Bierly, P. (2001). Analyzing innovation adoption using a knowledge-based approach. Journal of Engineering and Technology Management, 18, 107-118. http://dx.doi.org/10.1016/S0923-4748(01) 00031-5

Hopp, W.J., \& Spearman, M.L. (2004), "To pull or not to pull: what is the question?", Manufacturing \& Service Operations Management, 6(4), 133-48. http://dx.doi.org/10.1287/msom.1030.0028

iSixSigma "KLC, (2005) "Kaizen," Available URL: http://www.isixsigma.com/dictionary/Kaizen-42.htm, May 29, 2012.

Laraia, A. C., Moody, P. E., \& Hall, R. W. (1999), The Kaizen Blitz: Accelerating Breakthroughs in Productivity and Performance, New York: The Association for Manufacturing Excellence.

Lyu, J. J. (1996). Applying Kaizen and automation to process reenginering. Jurnal of Manufacturing System, 15(2).

Marksberry, P., Badurdeen, F., Gregory, B., \& Kreafle, K. (2010). Management directed kaizen: Toyota's Jishuken process for management development. Journal of Manufacturing Technology, 21(6), 670-686. http://dx.doi.org/10.1108/17410381011063987

Melnyk, S. A., Calantone, R. J., Montabon, F. L., \& Smith, R. T. (1998). "Short-term Action in Pursuit of Long-Term Improvements: Introducing Kaizen Events." Production and Inventory Management Journal, 39(4), 69-76.

Patil, H. (2003). "A Standard Framework for Sustaining Kaizen Events." Unpublished Master's Thesis. Department of Industrial and Manufacturing Engineering, Wichita: KS.

Prajogo, D.I., Power, D.J., \& Sohal, A.S. (2004). The role of trading partner relationships in determining innovation performance: An empirical examination. European Journal of Innovation Management, 7, 178-186. http://dx.doi.org/ 10.1108/14601060410549874

Recht, R., \& Wilderom, C (1998). 'Kaizen and culture: on the transferability of Japanese suggestion systems'. International Business Review, 7(1), 7-22. http://dx.doi.org/10.1016/S0969-5931(97)00048-6

Sheridan, J. H. (1997b), “Kaizen Blitz,” Industry Week, 246(16), 18-27.

Tanner, C., \& Roncarti, R. (1994), "Kaizen Leads to Breakthroughs in Responsiveness - and the Shingo Prize - at Critikon." National Productivity Review, 13(4), 517-531. http://dx.doi.org/10.1002/npr.4040130406 


\section{Macrothink}

Teece, D.J. (1998). Capturing value from knowledge assets: The new economy, markets for knowhow and intangible assets. California Management Review, 40(3), 55-79.

Van Aken, E. M., Farris, J. A., Glover, J. G., \& Letens, G. (2010). A framework for designing, managing, and improving Kaizen event programs. International Journal of Productivity and Performance Management, 59(7), 641-667. http://dx.doi.org/10.1108/17410401011075648

Venkataiah, C., \& Sagi, S. (2012). Relationship between kaizen event and perceived quality performance in Indian automobile industry. International Journal of Management and Business studies, 2(1), 2231-2463.

Watson, L. (2002). "Striving for Continuous Improvement with Fewer Resources? Try Kaizen,” Marshall Star, 28, 2002, pp. 1 (4 pgs).

Weerawardena, J., O'Cass, A., \& Julian, C. (2006). Does industry matter? Examining the role of industry structure and organizational learning in innovation and brand performance. Journal of Business Research, 59, 37-45. http://dx.doi.org/10.1016/j.jbusres.2005.02.004

Yamin, S., Gunasekaran, A., \& Mavonda, F.T. (1999). Relationship between generic strategies, competitive advantage and organizational performance: An empirical analysis. Technovation, 19, 507-518. http://dx.doi.org/10.1016/S0166-4972(99)00024-3

Zaugg, R., \& Thom, N. (2003). Excellence through implicit competencies: Human resource management-organizational development-knowledge creation. Journal of Change Management, 3, 199-211. http://dx.doi.org/10.1080/714042541 